\title{
Interfaith Dialogue Theory and Native/Non-Native RELATIONS
}

\author{
Jonathan NAPIER, University of CALGary
}

\begin{abstract}
Interfaith dialogue allows for an understanding of power relationships, a means of perceiving the Other, and a method of acquiring new knowledge. I will discuss the benefits and limitations of interfaith dialogue theory to Native/non-Native relations. Through interfaith dialogue, benefits such as relationship building and improved understanding provide opportunities to forge new communities within Canadian contexts. However, as is, the framework of interfaith dialogue also surfaces notions that prove problematic if applied directly to Native/non-Native relations. The framework of interfaith dialogue needs to be adjusted in order to be applied successfully in this area. Issues such as diverging worldviews, understandings of religion, misconceptions of the Other, political structures, and power discrepancies will all offer challenges and insights into how one applies aspects of interfaith dialogue. Furthermore, The non-Native community has a responsibility to reach out and change prevailing discrepancies in power structures.
\end{abstract}

$\mathrm{F}$ or the purposes of this paper the terms Native and non-Native will be used, and terms such as "Aboriginal" and "Indigenous" are used interchangeably. The term non-Native applies to all who settled after 1492, and includes the Canadian government and regular citizens (as each of these groups will have an impact on the analysis). While non-Native is a means of describing by negation, it is useful here because it allows for both distinction and broadness. This group would historically be considered Western or Judaeo-Christian, 
even though that does not accurately represent everyone who is not indigenous to Canada, especially today. As for those groups or individuals who do not fit nicely into either category, identity issues and legal placements aside, this paper is not intended to propose how individuals should self-identify (people will continue to mix or synthesize various sources for identity). ${ }^{1}$ Rather the focus is to present a means of relating with others despite our struggles with personal and interpersonal labels.

I will examine Native/non-Native relations as a part of interfaith dialogue for two reasons. First, it can be difficult to discern whether or not a discussion is religious, and things that are sacred or of religious significance are culturally specific. Second, the very notion of what is considered a religion, and what is not, is arguably different between those coming from a Native perspective and those coming from a non-Native one. ${ }^{2}$ Second, this perspective will allow for a broader application of the issues discussed: since not all interaction between Native and non-Native people can be considered religious, relations will be discussed in both secular and religious spaces. To promote understanding, the relations discussed are not always strictly endeavours of interfaith dialogue, but instead make use of, or could make further use of, interfaith dialogue theory. In this way I would like to look broadly at issues that arise in Native/non-Native communications and see how notions of interfaith dialogue can bring insight, perspective, and balance to these discussions.

Interfaith dialogue is essentially the discussion between adherents of two or more religious traditions. Conference-style formats focus on a particular topic, while small groups may meet regularly to discuss important aspects of their faith. Dialogue comes from the Greek words di and logos: "di" meaning two and "logos" meaning speech, or the reason that governs the universe, (e.g., divine wisdom). ${ }^{3}$ Interfaith dialogue focuses on various aspects of logos; it strives for insight and knowledge found in religious discourse. In this way, the particularity of a discussion defines what is a "better dialogue" than another because those judging the criteria would have to consider

1 An example of this process can be found in Thomas King, The Truth About Stories (Toronto: Anansi, 2003).

2 This will be discussed in greater depth later in this paper.

3 Webster's Ninth New Collegiate Dictionary (Springfield: Merriam-Webster, 1990), 349, 703. 


\section{Interfaith Dialogue Theory and \\ Native/Non-Native Relations}

what is most important to the religious traditions that are involved. In Greek terms this would be logos, but in current religious expression that which is most important is considered on a case by case basis. Interfaith dialogue is considered a means of encountering a religious Other.

Interfaith dialogue is often depicted as a means of building relationships. Canada's history can be described as a progression (and at times regression) of relationships between different groups. ${ }^{4}$ The potential for dialogue to privilege certain types of relationships is emphasized by Brice Balmer, who has been involved in organizing an interfaith dialogue group in his community. He emphasizes that "[w]hen people of faith share their convictions and talk about their practices in a non-coercive way, relationship and understanding develop." ${ }^{5}$ Since people are sharing deeply personal convictions, dialogue must be non-coercive. This sharing builds relationships founded on understanding, and can be a first step to improving the communications between Natives and non-Natives. The term noncoercive implies a dialogue that accepts diverging views and does not try to convert or convince anyone. The dialogue is treated as having intrinsic worth, versus being a tool of extrinsic value in which participants are seeking to simply promote their understanding of religion over those of others.

Because of the nature of interfaith dialogue, it can be far reaching and has the potential to self-perpetuate, ${ }^{6}$ and pushes boundaries while it affects the participants. Exposure to the Other provides a means of resolving misunderstandings, dissolving misconceptions, and eventually propelling participants to discover new truths together. ${ }^{7}$ People can be genuinely transformed by interfaith dialogue notes Mohammed Abu-Nimer: "One expectation of transformative

4 In fact, this is how Canada's history is described in We Get our Milk from the Land, eds. Lee Maracle, Jeannette C. Armstrong, Delphine Derickson and Greg Young-ing (Penticton: Thytus Books, 1993), 17.

5 Brice H. Balmer, Meeting our Multifaith Neighbors (Waterloo: Herald Press, 2006), 104.

6 Ewert H. Cousins, "Interreligious Dialogue: The Spiritual Journey of Our Time," in Interreligious Dialogue: Voices From a New Frontier, ed. M. Darrol Bryant and Frank Flinn (New York: Paragon House, 1989), 6.

7 Leonard Swidler, "Ground Rules for Interreligious Dialogue." in Interreligious Dialogue: Facing the Next Frontier, ed. Richard W. Rousseau (Scranton: Ridge Row Press, 1981), 11-12. 
[interfaith dialogue] is that participants will, in some way, behave differently after the dialogue." 8 Participants can become more knowledgeable about each other and more compassionate, ${ }^{9}$ and can reach deeper mutual understandings of religious complexity..$^{10}$ It is clear that interfaith dialogue is a promising community-building tool. Balmer describes this desirable atmosphere as a space where "individuals speak from a 'for me' perspective and do not proselytize; [where] relationships are formed through regular monthly meetings; people are given equal opportunity to speak and listen throughout the dialogue." 11

Two key concepts of interfaith dialogue are its ability to recognize differences among participants and its commitment to not attempting to reach consensus. One way to accommodate difference is to pay attention to language barriers: whose language is used to conduct discussions and in what space matters for the outcome. ${ }^{12}$ When people feel comfortable communicating, true dialogue can begin. Shapiro notes, "Here the emphasis is not to state positions but to understand the person. Here the emphasis is not on doctrine or dogma but on the human quest for meaning, purpose and wonder." ${ }^{13}$ This type of dialogue will "honor the differences in faith at the same time... recognize similarities." ${ }^{14}$ In this way the unity and community built around dialogue does not promote sameness. If there are similarities, they are shared. If there are differences, they are respected. Paul Mojzes points out this guiding principle: "no synthesis is expected."15 It is important for participants to feel comfortable and not to be forced, overtly or covertly, to compromise or change their beliefs. Authentic interfaith dialogue is focused on the human aspect rather than predetermined theological outcomes. ${ }^{16}$ This can have a profound

8 Mohammed Abu-Nimer, Amal L. Khoury, and Emily Welty, Unity in Diversity: Interfaith Dialogue in the Middle East (Washington: United States Institute of Peace Press, 2007), 16.

9 Ibid.

10 Ibid., 37-38.

11 Balmer, 104.

12 Abu-Nimer, et al., 40.

13 Rami, Mark Shapiro, "Moving the Fence: One Rabbi's View of Interreligious Dialogue," in Bryant and Frank, 39.

14 Abu-Nimer et al., 15.

15 Paul Mojzes, "The What and How of Dialogue," in Bryant and Frank, 206.

16 Ibid., 203. 


\section{Interfaith Dialogue Theory and \\ Native/Non-Native Relations}

impact on Native/non-Native relations, particularly in discussions about land claims or governing issues that are centred on conclusionbased negotiations.

How relevant are these notions are for Native/non-Native relations? For this analysis I turn to Jessie Sutherland from British Columbia, who has dedicated her work to personal and political transformation, reconciliation, and promoting better relations between Native/non-Native communities. She organizes workshops to promote communication between communities and organizes discussions and dialogues throughout Canada. Sutherland uses media and technology to overcome geographic hurdles and allow restoration and peace work to take place. Much of her language exemplifies interfaith dialogue, and she has applied these notions to her work. ${ }^{17}$ In her assessment, many of the issues surrounding Native/nonNative relations could be addressed through strategies of interfaith dialogue. ${ }^{18}$ She applies these principles to improve communication generally.

A main focus of Sutherland's work is harmony. There have been many disruptions in the relationship between Natives and nonNatives; however, these communities need to reach a point where work and communication can be effective. Sutherland calls for "worldview pluralism," which she defines as allowing for "coexistence between diverse relationships to truth and reality and the various ways human culture expresses these beliefs." ${ }^{19}$

A pluralistic worldview helps create a cognitive space for Natives and non-Natives to discuss spirituality. Deloria Vine, writing on aboriginal identity formation and negotiation, draws a link between worldviews and Indigenous spirituality. ${ }^{20}$ A primary need for Native/ non-Native relations, according to Sutherland, is understanding

17 Jessie Sutherland, Worldview Skills: Transforming Conflict from the Inside Out (Vancouver: Worldview Strategies, 2005), 9. Sutherland speaks of "healing," "reconciliation," "transformation," "heart and soul," "spirit and will," and "harmony," all terms that are common in religious discourse and interfaith dialogue theory.

18 Although Sutherland does not use the term "interfaith dialogue" outright, she does use similar concepts.

19 Sutherland, Worldview Skills, 15.

20 Deloria Vine, The Metaphysics of Modern Existence (San Francisco, Harper \& Row, 1979), 151-152. 
worldviews. Thus, religion needs to be considered. Many issues regarding contact between Native and non-Native people have a religious dimension, ${ }^{21}$ and the use of religion allows for integral aspects of a person's identity, otherwise overlooked, to be included in the discussion. ${ }^{22}$ Therefore, interfaith dialogue offers a means of addressing these issues in a way other communicative models cannot.

To employ interfaith dialogue theory it is important to recognize one's definition of "faith"; it is widely used as a substitute for the word "religion." Willard Oxtoby and Alan Segal note that "it seems impossible to identify any feature that is absolutely essential in order for a tradition to qualify as a religion." ${ }^{23}$ For some Indigenous people, the term "religion" comes from a Christian context, meaning that Christianity was the ideal prototype..$^{24}$ Some scholars describe Indigenous religions as "primitive," "tribal," or "traditional"-all of which are demeaning and inappropriate descriptions. ${ }^{25}$

Initial relations between Natives and non-Natives were based on attempts to convert Natives from their "false beliefs." ${ }^{26}$ When in a textbook, Oxtoby and Segal describe Indigenous religions of Central and South America, they focus on rituals, beliefs, and other aspects

21 Alfred Taiaiake describes the religious aspect from an Indigenous perspective in a way that is meant to be empowering for one group (Natives) and does not focus on the other (non-Natives). However his bringing in the religious dimension to the discussion is worth noting as it is something that could be addressed by those willing to participate in dialogue. Alfred Taiaiake, Wasáse: Indigenous Pathways of Action and Freedom (Peterborough: Broadview Press, 2005), 31.

22 Abu-Nimer, et al. describe how in Israel-Palestine ignoring religious aspects of identity results in not achieving reconciliation; religion is a part of the equation that cannot be ignored. Abu-Nimer, et al. , 43-44.

23 Willard G. Oxtoby and Alan. F. Segal, "The Nature of Religion," in A Concise Introduction to World Religions (Toronto: Oxford University Press, 2007), 557.

24 Ibid., 555-557.

25 The issue of labelling is discussed in Robert M. Baum's "Indigenous

Religions," in A Concise Introduction to World Religions, edited by Willard G, Oxtoby and Alan F. Segal (Toronto: Oxford University Press, 2007), 11.

26 While some Jesuit missionaries were kinder in tone, there was a prevalence of dismissal of Indigenous beliefs and even outright mocking. For example, see Jean De Brébeuf, "Religion, Myth and Ritual," in The Jesuit Relations: Natives and Missionaries in Seventeenth-Century North America, trans and ed. Allan Green (New York: Bedford/St. Martin's, 2000). Most notably Brébeuf describes Indigenous practices containing "blindness in regard to things of heaven," "fables," (41) the people themselves as "worse than beasts in God's sight," (42) and ultimately false and foolish(46). 


\section{Interfaith Dialogue Theory and \\ Native/Non-Native Relations}

often considered integral parts of religion. Unfortunately, the authors "mix and match" many Native tribes and nations, combining all beliefs into the "Indigenous religions of Central and South America." ${ }^{27}$ This can be contrasted with Vine's description of Native religion as context and relationships with the land, the people, the spirits and the place in time. ${ }^{28}$ These perspectives are lacking in a textbook study which clumps all Indigenous religions of the world into one chapter. Winona LaDuke, a woman of Native ancestry, does not even describe herself as participating in a "religion"; rather she describes her "spirituality".29 She acknowledges the problematic aspects of the term "religion" by avoiding it altogether. Indigenous people have tried valiantly to fit their experiences into languages, terms, and worldviews that are not their own. LaDuke raises the issue of why Indigenous religions are often referred to as spiritualities; they do not have some of the key aspects of an historically prototypical religion, e.g., texts, one or many gods, and certain rituals. However, the value of oral traditions, myth, and other approaches to religion can be encouraged by interfaith dialogue.

Another difficulty with dialogue is the issue of diverging understandings of religion and its role in the world. Religion can be seen in opposition to the secular. There is a rift created by a Western understanding that Vine asserts is not relevant to an Indigenous religious perspective. Charles Taylor describes the relationship people have had between the secular and the spiritual in terms of a "historical frame". He states that the people of the Western world became disenfranchised with a religious worldview and turned (be it slowly and not completely) to a secular worldview. To explain this, Taylor introduces his "immanent frame" which describes how people understand their relation to the supernatural. People either live in interaction with the supernatural or live separate from it. Taylor depicts this as a divide between the porous and the buffered self. The porous self has an enchanted worldview; it sees itself as interacting with the spiritual world; it is vulnerable and open to forces beyond the

27 Baum, 32-38.

28 Deloria Vine, God is Red: A Native View of Religion (New York; Grosset \& Dunlap, 1973), 65-66.

29 Winona LaDuke and Huston Smith, A Seat at the Table: Hudson Smith in Conversation with Native Americans on Religious Freedom (Berkeley; University of California Press, 2006), 55. 
physical realm. ${ }^{30}$ There is power in objects and places, and "the line between personal agency and impersonal force was not at all clearly drawn." ${ }^{31}$ However, disenchantment takes place and people become buffered, unaffected by spirits and in control of their own destiny. ${ }^{32}$ The buffered self becomes focused on privacy, intimacy, inwardness, and individualism. ${ }^{33}$

This perspective sits in contrast to Native focus on context, outwardness, relationships, and the land. Vine does not recognize this disenchantment; he regards Indigenous religious perspectives as what could be described as porous. ${ }^{34} \mathrm{He}$ asserts that, unlike Euro-normative traditions, Indigenous religions have not divided their experiences into the two realms of material and spiritual. ${ }^{35}$ Experience is mixed in with understanding religious truths. There is no separation or inward scope in Indigenous religion. Vine makes this point when he remarks, "This view of primitive peoples provides them with an understanding of the natural world that immediately incorporates all aspects of experience." ${ }^{36}$ In this way Indigenous religions incorporate all aspects of experiencing, spiritual and, what Taylor would describe as secular, into one way of understanding. This appropriates a unity of knowledge and understanding that is compartmentalized in Western thinking. ${ }^{37}$ Spirits affect people and vice versa. ${ }^{38}$ However, this is not the same as a "primitive" versus "developed" worldview model. Rather, this is simply a diverging means of experiencing the world, each legitimate. This concerns what we consider religious and how one experiences religion. ${ }^{39}$ Dialogue can overcome this, and can contribute to the

30 Charles Taylor, A Secular Age (Cambridge: The Belknap Press of Harvard University Press, 2007), 32.

31 Ibid.

32 Ibid., 38.

33 Ibid., 541.

34 Although Vine does not make any direct reference to Taylor's work himself. 35 Vine, The Metaphysics of Modern Existence, 151.

36 Ibid., 158.

37 Ibid.,13; and Richard K. Nelson, "The Watchful World," in Reading in Indigenous Religions, ed. Graham Harvey (New York: Continuum, 2002), 357.

38 Nelson, "The Watchful World," 357.

39 This is apparent in Vine's comparison of Christianity to Indigenous religions and their relationship to the land. Vine asserts the Indigenous people have a stronger connection to the land, which he provides as reasons for promoting Indigenous religion over Christianity. This is a stance that was necessary in Vine's 


\section{Interfaith Dialogue Theory and \\ Native/Non-Native Relations}

promotion of understanding religion in different ways, not holding one view above the other. The fact that there are differing worldviews allows for interfaith dialogue to provide a space where individuals can work out their understandings of religion with one another. Theorists like Taylor and Vine often present generalizations, these frameworks understanding and interpreting the world can be synthesized, hybridized, and clarified for those who actually partake in dialogue.

Understandings of religion and secularity can affect interfaith dialogue, and so can the ways in which persons live out their faith. The renowned Jewish thinker Joshua Abraham Heschel states that the "first and most important prerequisite of interfaith is faith." 40 Interfaith dialogue consistently calls upon those who are faithful to their religion to participate; not those who are considered spiritually immature. This condition is described as a need for having roots within one's own faith before one can adequately share in encounters with another. ${ }^{41}$ Sharing faith can be challenging for any tradition. ${ }^{42}$ Vine states that Native faith can be difficult for some to articulate, and some lack the confidence or conceptual framework to do so. ${ }^{43}$ There is also a hesitancy among elders to even want to share Native spirituality with non-Natives. ${ }^{44}$ In order to promote understanding and to build relationships these different contexts are important to recognize.

Another important issue is power structure. Since non-Natives are the majority in Canada and hold more influence in the government, there is a systemic and societal power inequality. Interfaith dialogue calls for equality amongst the participants. In the context of Jewish-

time of writing God is Red, however, the ideal is to promote a situation where mutual understanding and respect can be achieved instead of competition for acknowledgement. See Vine, God is Red, 295-96.

40 Joshua Abraham Heschel, "No Religion is an Island," in Christianity Through Non-Christian Eyes, ed. Paul J. Griffiths (Maryknoll: Orbis, 1990), 32. M. Darryl Bryant and Frank K. Flinn, "Introduction: Scouting the Frontier," in Bryant and Flinn, xx.

41 Heschel, "Scouting the Frontier," xx.

42 This notion of the ability for one to share their faith is discussed by Eugene Korn in his analysis of Soloveitchik's "Confrontation," where he states that it is possible, but not always easy. Eugene Korn, "The Man of Faith and Religious Dialogue: Revising 'Confrontation,” Modern Judaism 25(1994): 290-315.

43 Vine, The Metaphysics of Modern Existence, xii.

44 Gkisedtanamoogk and Frances Hancock, Ceremony is Life Itself (Nobleboro: Blackberry Books, 1993), 37. 
Christian dialogue, discussions put an imposition on the Jewish people, which is why Soloveitchik sets out limitations and conditions for dialogue between Jews and Christians. ${ }^{45}$ This is similar to the Native context. Soloveitchik states that both eschatological exclusivism and proselytizing are problematic. ${ }^{46} \mathrm{He}$ is also aware of other effects of power dynamics; that Christians will be theologically condescending towards Jews. "We are not ready for a meeting with another faith community in which we shall become an object of observation, judgment and evaluation, even though the community of the many may then condescendingly display a sense of compassion with the community of the few and advise the many not to harm or persecute the few." ${ }^{47}$ Soloveitchik calls for the recognition of difference, intrinsic worth of the Jews, and equal religious freedom. ${ }^{48}$ The importance of recognizing history is another factor that is necessary for dialogue to take place. ${ }^{49}$

When considering Native and non-Native dialogue there is burden on Native people in the form of language, structures for dialogue, and shared knowledge..$^{50}$ Native people need to appreciate who they are, not stereotyped, and to listen to self-projection and self-identification as opposed to images that have been placed on Native people by outsiders. $^{51}$

When considering the application of interfaith dialogue theory it is important to keep in mind what kind of dialogues are achievable. For short-term, specific projects, interfaith dialogue may be less effective because in order to produce results a long time is needed and results are very dependent on the participants' commitment. For those interested in applying interfaith dialogue models to relationship building it is important to understand what the government is doing, and to be conscious of how involved the government is going to be

45 Joseph B. Soloveitchik, "Confrontation" Tradition: A Journal of Orthodox Thought 6, 2 (1964): 6.

46 Ibid.

47 Ibid.

48 Ibid.

49 Korn, "The Man of Faith and Religious Dialogue."

50 Noel Dyck. What is the Indian "Problem": Tutelage and Resistance in Canadian Indian Administration (St John's: The Institute of Social and Economic Research, 1991), 12.

51 Dyck, 20-21. 


\section{Interfaith Dialogue Theory and \\ Native/Non-Native Relations}

in the dialogue. ${ }^{52}$ Government treaties, apologies, and policy affect on-the-ground communication and relationship building. These can be stepping stones or stumbling blocks. ${ }^{53}$ To critically assess the role of interfaith dialogue in particular cases there are always many factors involved. It is worth recognizing, however, that the concepts and tools provided by interfaith dialogue can and ought to be adapted and moulded to various situations when applied. By addressing the specifics of context and participant situations interfaith dialogue can be a powerful tool for brining about transformation.

The relationship between Native people and non-Native people is ongoing. One cannot critically consider all the facets of this relationship and provide theoretical frameworks that will apply to every aspect. Interfaith dialogue does provide insight. Further research is needed to mould and shape interfaith dialogue theory to include the Native/ non-Native context. Respect for differences increases understanding and appreciation of the. Continued efforts to increase understanding and community building are necessary, and the ideals and aspects of interfaith dialogue can help provide support for these projects.

\section{Bibliography}

Abu-Nimer, Mohammad, Amal I. Khoury, and Emily Welty. Unity in Diversity. Interfaith Dialogue in the Middle East. Washington: United States Institute of Peace Press, 2007.

Balmer, Brice, H. Meeting Our Multifaith Neighbors. Waterloo: Herald Press, 2006.

Bryant, M. Darryl, and Frank K. Flinn, eds. Interreligious Dialogue: Voices from a New Frontier. New York: Paragon House, 1989.

Cousins, Ewert H. "Interreligious Dialogue: The Spiritual Journey of Our Time." Interreligious Dialogue: Voices from a New Frontier,

52 Abu-Nimer et al., 215.

53 Ibid., 217. 
ed. M. Darrol Bryant and Frank Flinn. New York: Paragon House, 1989.

De Brébeuf, Jean. "Religion, Myth and Ritual." The Jesuit Relations:

Natives and Missionaries in Seventeenth-Century North America, trans and ed. Allan Green. New York: Bedford/St. Martin's, 2000.

Dyck, Noel. What is the Indian "Problem": Tutelage and Resistance in Canadian Indian Administration. St John's: The Institute of Social and Economic Research, 1991.

Gkisedtanamoogk, and Frances Hancock, Ceremony is Life Itself. Nobleboro: Blackberry Books, 1993.

Heschel, Joshua Abraham. "No Religion is an Island." Christianity through Non-Christian Eyes. ed. Paul J Griffiths Maryknoll: Orbis, 1990.

Indian and Northern Affairs Canada. "Peace and Friendship Treaties." http://www.aincinac.gc.ca/al/hts/tng/ecn/pft/index-eng. asp (accessed on April 14, 2009).

King, Thomas. The Truth about Stories: A Native Narrative. Toronto: Anansi, 2003.

Korn, Eugene. “The Man of Faith and Religious Dialogue: Revising 'Confrontation.”' Modern Judaism 25 (1994): 290-315.

LaDuke, Winona, and Huston Smith. A Seal at the Table: Hudson Smith in Conversation with Native Americans on Religious Freedom. Berkeley: University of California Press, 2006.

Maracle, Lee, and Jeanette C. Armstrong, Delphine Derickson and Grer Youngingm, eds. We get Our Living Like Milk from the Land. Penticton: Thytus Books, 1993.

Mojzes, Paul. "The What and How of Dialogue." Interreligious Dialogue: Voices From a New Frontier, ed M. Darrol Bryant and Frank Flinn. New York: Paragon House, 1989, pp. 199-206. 


\section{Interfaith Dialogue Theory and \\ Native/Non-Native Relations}

Nelson, Richard K. "The Watchful World." In Reading in Indigenous Religions, ed. Graham Harvey. New York: Continuum, 2002, pp. 343-64.

Oxtoby, Willard G., and Alan. F. Segal, "The Nature of Religion," in A Concise introduction to World Religions. Toronto: Oxford University Press, 2007.

Peacemakers Trust. "Peacemakers Trust: A Non-Profit Charity Registered in Canada. http://wwwpcacemakers. caIPeacemakersTrustBrochure.htm1 (accessed on April14, 2009).

Schouls, Tim. Shifting Boundaries: Aboriginal Identity, Pluralist Theory and the Poll/icy of Self-Government. Vancouver: UBC Press, 2003.

Shapiro, Rami Mark. "Moving the Fence: One Rabbi's View of Interreligious Dialogue." In Interreligious Dialogue: Voices From a New Frontier, edited by M. Darrol Bryant and Frank Flinn, 3: 1-40. New York: Paragon House, 1989.

Smith, Jonathan Z. "Religion, Religions, Religious." In Relating Religion: Essays in the Study of Religion, edited by Jonathan $Z$. Smith, 179-196. Chicago: University of Chicago Press, 2004.

Smith, Jonathan Z.. "A Matter of Class: Taxonomies of Religion." Relating Religion: Essays in the Study of Religion, edited by Jonathan Z. Smith, 160-178. Chicago: University of Chicago Press, 2004.

Soloveitehik, Josehp B. "Confrontation." Tradition: A Journal of Orthodox Thought 6, 2(1964): 5-9.

Sutherland, Julie. Worldview Skills Transforming Conflict from the Inside Out. Vancouver: Worldview Strategies, 2005.

Swidler, Leonard. "Ground Rules for Interreligious Dialogue." Interreligious Dialogue: Facing the Next Frontier, edited by 
Richard W. Rousseau, 9-12. Scranton: Ridge Row Press, 1981.

Taiaiake, Alfred. Wasáse: Indigenous Pathways of Action and Freedom. Peterborough: Broadview Press, 2005.

Taylor, Charles. A Secular Age. Cambridge: The Belknap Press of Harvard University Press, 2007.

Vine, Deloria. God is Red: A Native View of Religion. New York: Grosset \& Dunlap, 1973.

Vine, Deloria. The Metaphysics of Modern Existence. San Francisco: Harper \& Row, 1979.

Webster Ninth New Collegiate Dictionary. Springfield: MerriamWebster, 1990.

Worldview Strategies. "About Us." Worldview Strategies. http://www. worldviewstrategies.com (accessed on April 14, 2009). 